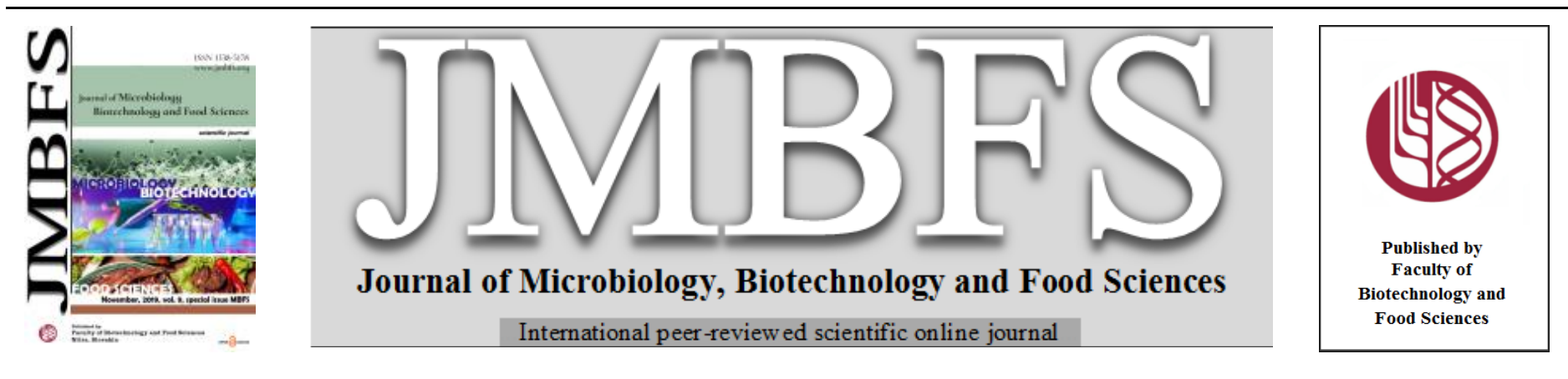

\title{
EFFECT OF PEPTIDOGLYCAN ON EXPRESSION OF CD44 ON BOVINE MAMMARY GLAND LYMPHOCYTES
}

\author{
Petr Slama*, Terezie Zavadilova, Lucie Kratochvilova, Kristina Kharkevich
}

Address(es): Ing. Petr Slama, Ph.D.

Mendel University, Faculty of AgriSciences, Department of Animal Morphology, Physiology and Genetics, Zemedelska 1, 61300 Brno, Czech Republic, phone number: +420 545133146 .

*Corresponding author: petr.slama@mendelu.cz

doi: 10.15414/jmbfs.2019.9.special.447-448

\section{ARTICLE INFO}

Received 2. 8. 2019

Revised 12.9. 2019

Accepted 13. 9. 2019

Published 8. 11. 2019

Regular article

OPEN $\partial_{\text {ACCESS }}$

\begin{abstract}
The aim of this study was to analyze changes in the expression of CD44 on bovine mammary gland lymphocytes during experimental infection caused by peptidoglycan of Staphylococcus aureus. Lymphocytes were obtained by lavage of the mammary glands at four intervals (24, 48, 72 and 168 hours) following experimental intramammary injection of peptidoglycan. The percentage of CD44 positive lymphocytes peaked at 24 and 48 hours following infection with peptidoglycan of Staphylococcus aureus. The results show that during the experimental infection the expression of CD44 on lymphocytes is induced in early stage of mastitis (till 48 hours from the stimulation of inflammation). In the resolution of mastitis, CD44 expression is dramatically decreased.
\end{abstract}

Keywords: peptidoglycan, lymphocyte, CD44, Staphylococcus aureus, mammary gland, mastitis

\section{INTRODUCTION}

Staphylococcus aureus is very important pathogen causing bovine mastitis (Petersson-Wolfe et al. 2010) with high economic loss for dairy farmers (Heikkila et al., 2018). These bacteria contain peptidoglycan in the cell wall. Peptidoglycan is also found in the cell wall of Gram-negative bacteria but in different structure than in Gram-positive bacteria (Vollmer et al., 2008) Peptidoglycan is able to induce inflammatory response of bovine mammary gland (Furukava et al., 2018).

CD44 is an adhesion receptor that is associated with different biologica processes including inflammation. Increased amount of CD44 remains on the surface of memory $\mathrm{T}$ lymphocytes mediate protection against re-infection (Baaten et al., 2010). This glycoprotein is multifunctional and it is involved in aggregation, migration, and activation of cells (Heider et al., 1993; Senbanjo and Chellaiah, 2017). Bacteria or their components or toxins are able to influence expression of CD44 receptor on the cell membrane of different immune cells. There were analyzed the effect of muramyl dipeptide and lipopolysaccharide on the expression of CD44 on neutrophils (Langrova et al., 2008) and macrophages (Sladek and Rysanek, 2009). The effect of those bacterial components on CD44 expression was primarily evident during initial stage of the inflammation. High expression of CD44 in the resolution of inflammation can be related to macrophages involvement in the processes of renewing of injured tissues (Sladek and Rysanek, 2009). In the early stage of the inflammation, there was a gradual increase in the portion of CD44 positive neutrophils. The percentage of CD44 positive neutrophils is low in the start of inflammation and therefore CD44 is not marker of activation of neutrophils (Langrova et al., 2008).

The goal of this study was to analyze whether expression of CD44 receptor on bovine mammary gland lymphocytes is modulated during an inflammatory response induced by peptidoglycan.

\section{MATERIAL AND METHODS}

Experimental design: Eight clinically healthy virgin heifers (Holstein $x$ Bohemian Red Pied crossbred) aged 16 to 18 months were used for our experiments. All these animals were free of infection of the udder. Bacteriological examination of mammary gland lavages was executed by culturing on blood agar with aerobic incubation at $37^{\circ} \mathrm{C}$ for 24 hours.

For the experimental infection, there were used urethral catheter (AC5306CH06, Porges SA, France) to inject into the teat canal after disinfection of the teat orifice (Sladek et al., 2005; Slama et al., 2009). Each mammary gland of the udder was injected with $20 \mathrm{ml}$ phosphate buffered saline (PBS) with $50 \mu \mathrm{g}$ of peptidoglycan of $S$. aureus (Sigma, USA). The first sample of cells was obtained by PBS lavage of right-front quarter in 24 hours, right-rear quarter in 48 hours, left-front quarter in 72 hours, and left-rear quarter in 168 hours following peptidoglycan challenge. Before experimental infection, the mammary glands were used for preparation of control samples through treatment by PBS which was previously described by Sladek et al., (2005).

The lymphocytes obtained by lavages of mammary glands were processed to detect CD44 positive lymphocytes by flow cytometry (FACS Calibur Apparatus, Becton Dickinson, CA, USA) and subsequently by software WinMDI 2.8 (Trotter, 2000) as in previous study. Mouse anti-ovine antibody CD44 BAG40A (VMRD Inc. Pullman, Washington, USA) and IgG3 (SouthernBiotech,Birmingham, Alabama, USA) were used as the primary and the secondary antibody (Langrova et al., 2008).

For statistical analysis, there were used statistical software STATISTICA 8.0 (StatSoft, Czech Republic). Arithmetic means and standard deviations were used to describe CD44 positive lymphocytes. Statistically significant differences in the proportion of CD44 positive lymphocytes were determined by paired $t$-test.

\section{RESULTS AND DISCUSSION}

The aim of this study was to evaluate the effect of peptidoglycan on the lymphocyte CD44 expression during experimentally induced inflammation. In our experiments, the expression of CD44 receptor on the cell membrane of lymphocytes was changed during the inflammatory response. Experimental infusion of peptidoglycan into the mammary gland led to increase of CD44 positive lymphocytes with the maximum in 24 and 48 hours following infection of the mammary glands compare to the control (Figure 1). 


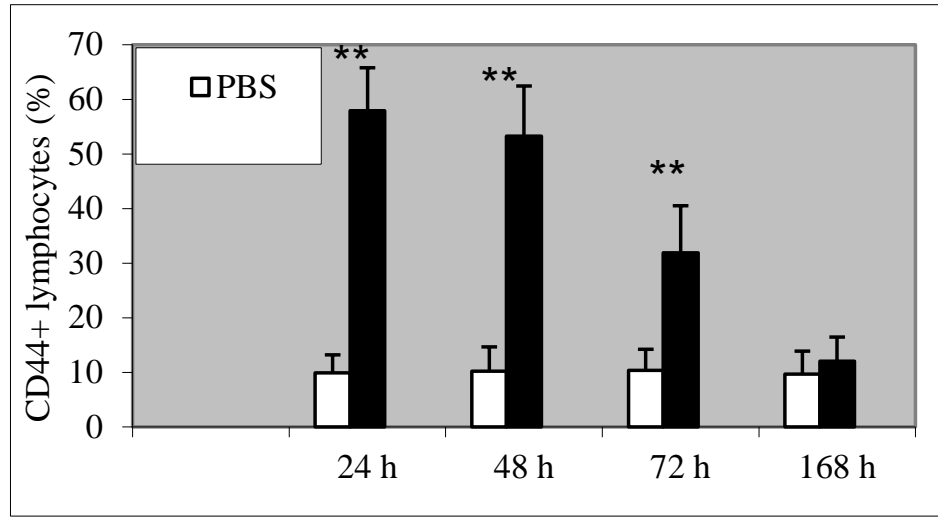

Figure 1 CD44 positive lymphocytes (\%) following stimulation by peptidoglycan in four timepoints $(24,48,72,168$ hours). PBS - phosphate buffered saline; ** $\mathrm{P}<0.01$

These results suggest that peptidoglycan can induce expression of CD44 on lymphocytes in the initial phase of inflammation. Contrary to that, the previous study showed gradual increase of CD44 expression on neutrophils in experimental inflammation of the udder using lipopolysaccharide and muramy dipeptide (Langrova et al., 2008). This comparison indicates the different role of this receptor on lymphocytes and neutrophils. In the population of macrophages, there is different expression between two subpopulation of macrophages (nonvacuolised x vacuolised) (Sladek and Rysanek, 2009). Vacuolised macrophages has similar trend of CD44 expression as neutrophils. Baaten et al. (2010) refer about the importance of this adhesion receptor to immune cell regulation and protection against intracellular bacteria. S. aureus is also able to internalize and survive within host immune cells (Hamza et al., 2013) and therefore we suggest that component of the cell wall of that bacteria as peptidoglycan is involved in the process of activation of immune cells, internalization of the bacteria into host cells and expression of CD44 of host cells including lymphocytes. The expression of CD44 on lymphocytes probably correlates with apoptosis of lymphocytes in the first stage of mastitis (unpublished preliminary results).

\section{CONCLUSION}

The results suggest that peptidoglycan can modulate expression of CD44 receptor on the cell membrane of lymphocytes during the process of inflammation of the mammary gland. We studied whole population of lymphocytes and therefor it is necessary to continue to investigate different subpopulation of lymphocytes. Different subpopulation of lymphocytes could have different expression of CD44.

Acknowledgments: The authors wish to express their thanks for financial support to the projects of IGA AF MENDELU No. AF-IGA-2018-tym002.

\section{REFERENCES}

BAATEN, B.J.G., LI, C.R., BRADLEY, L.M. 2010. Multifaceted regulation of T cells by CD44. Communicative and Integrative Biology, 3, 508-512. http://dx.doi.org/10.4161/cib.3.6.13495

FURUKAVA, M., YONEYAMA, H., HATA, E., IWANO, H., HIGUCHI, H., ANDO, T., SATO, M., HAYASHI, T., KIKU, Y., NAGASAWA Y., NIIMI, K., USAMI, K., ITO, K., WATANABE, K., NOCHI, K., ASO, H. 2018. Identification of a novel mechanism of action of bovine $\mathrm{IgG}$ antibodies specific for Staphylococcus aureus. Veterinary Research, 49, 22 http://dx.doi.org/10.1186/s13567-018-0517-y

HAMZA, T., DIEZT, M., PHAM, D., CLOVIS, N., DANLEY, S., LI, B., 2013. Intra-cellular Staphylococcus aureus alone causes infection in vivo. European Cells and Materials, 25, 341-350. http://dx.doi.org/10.22203/eCM.v025a24

HEIDER, K.H., HOFMANN, M., HORS, E., VAN DEN BERG, F., PONTA, H., HERRLICH, P., PALS, S.T. 1993. A human homologue of the rat metastasisassociated variant of CD44 is expressed in colorectal carcinomas and adenomatous polyps. Journal of Cell Biology, 120, 227-233. http://dx.doi.org/10.1083/jcb.120.1.227

HEIKKILA, A.M., LISKI, E., PYORALA, S., TAPONEN, S. 2018. Pathogenspecific production losses in bovine mastitis. Journal of Dairy Science, 101 9493-9504. http://dx.doi.org/10.3168/jds.2018-14824

LANGROVA, T., SLADEK, Z., RYSANEK, D. 2008. Expression of CD14 and CD44 on bovine polymorphonuclear leukocytes during resolution of mammary inflammatory response induced by muramyldipeptide and lipopolysaccharide. Veterinarni medicina, 53, 1-11. http://dx.doi.org/10.17221/1935-VETMED PETERSSON-WOLFE, C.S., MULLARKY, I.K., JONES, G.M. 2010. Staphylococcus aureus mastitis: cause, detection, and control. Virginia Cooperative Extension, 404-229.
SENBANJO, L.T., CHELlAIAH, M.A. 2017. CD44: A Multifunctional Cell Surface Adhesion Receptor Is a Regulator of Progression and Metastasis of Cancer Cells. Frontiers in Cell and Developmental Biology, 5,18. http://dx.doi.org/10.3389/fcell.2017.00018

SLADEK, Z., RYSANEK, D. RYZNAROVA, H., FALDYNA, M. 2005 Neutrophil apoptosis during experimentally induced Staphylococcus aureus mastitis. Veterinary Research, 36, 243-262. http://dx.doi.org/10.1051/vetres:2005023

SLADEK, Z., RYSANEK, D. 2009. Expression of macrophage CD44 receptor in the course of experimental inflammatory response of bovine mammary gland induced by lipopolysaccharide and muramyl dipeptide. Research in Veterinary Science, 86, 235-240. http://dx.doi.org/10.1016/j.rvsc.2008.07.016

SLAMA, P., SLADEK, Z., RYSANEK, D., LANGROVA, T. 2009. Effect of Staphylococcus aureus and Streptococcus uberis on apoptosis of bovine mammary gland lymphocytes. Research in Veterinary Sciences, 87, 233-238. http://dx.doi.org/10.1016/j.rvsc.2009.03.005

TROTTER, J.: WinMDI Version 2.8. 2000. http://facs.scripps.edu/.

VOLLMER, W., BLANOT, D., DE PEDRO, M.A. 2008. Peptidoglycan structure and architecture. FEMS Microbiology Reviews, 32, 149-167. http://dx.doi.org/10.1111/j.1574-6976.2007.00094.x 